\title{
Pemanfaatan Serbuk Kulit Kerang Sebagai Pengganti Agregat Halus Terhadap
}

\section{Kuat Tekan Beton}

\author{
Rofikatul Karimah $^{1}$, Yunan Rusdianto ${ }^{2}$, Desy Putri Susanti ${ }^{3}$ \\ 1,2,3 Jurusan Teknik Sipil, Fakultas Teknik, Universitas Muhammadiyah Malang \\ ${ }^{1}$ Email : rofikatulkarimah@gmail.com
}

\begin{abstract}
Abstrak
Sejumlah penelitian teknologi kontruksi terus dikembangkan dengan tujuan dapat menghasilkan teknologi kontruksi yang tepat guna. Salah satunya dengan memanfaatkan serbuk kulit kerang yang dihasilkan oleh 89 unit pengolahan kerang di Desa Campurejo, Gresik. Dari 1 unit pengelolahan kerang mampu memanen $\pm 100 \mathrm{~kg}$ setiap minggunya. Dari kegiatan tersebut dapat menghasilkan limbah padat berupa serbuk kulit kerang yang cukup tinggi. Untuk mengurangi dampak lingkungan dan kesehatan yang disebabkan oleh limbah tersebut, maka dilakukan pemanfaatan limbah serbuk kulit kerang sebagai bahan pengganti agregat halus pada campuran beton. Penelitian ini dilakukan untuk mengetahui pengaruh penggunaan serbuk kulit kerang sebagai pengganti agregat halus terhadap kuat tekan beton. Variasi penggunaan serbuk yang digunakan sebesar $0 \%, 5 \%, 10 \%, 15 \%, 20 \%, 25 \%$, dan 30\% dari berat agregat halus dengan FAS 0,6. Hasil pengujian diperoleh nilai kuat tekan beton mengalami kenaikan pada prosentase $10 \%$ dan selanjutnya kuat tekan beton menurun seiring dengan pertambahan prosentase penggunaan serbuk kulit kerang. Sedangkan nilai absorbsi beton mengalami kenaikan pada prosentase $30 \%$ dari berat agregat halus.
\end{abstract}

Kata kunci : Campurejo, Kuat tekan beton, Serbuk kulit kerang, Teknologi Konstruksi.

\section{Pendahuluan}

Pada masa sekarang perkembangan teknologi diberbagai bidang telah berkembang dengan pesat. Tak hanya dibidang ilmu pengetahuan dan informasi, dibidang kontruksi juga telah berkembang dengan pesat. Sejumlah penelitian teknologi kontruksi terus dikembangkan dengan tujuan dapat menghasilkan teknologi kontruksi yang tepat guna. Penelitian bahan material alternative merupakan sesuatu yang sering dijadikan obyek penelitian, sebab dengan ditemukan bahan alternatif yang tepat, maka akan dapat berpengaruh pada pengurangan jumlah bahan baku yang biasa kita gunakan.

Penduduk di Desa Campurejo Kecamatan Panceng Kabupaten Gresik sebagian besar mempunyai mata pencaharian sebagai nelayan dan juga sebagai petani kerang. Di Desa Campurejo memiliki 89 unit pengolahan kerang, dari setiap 1 unit kerang mereka mampu memanen $100 \mathrm{~kg}$ setiap minggunya (Badrus, 2015). Bisa kita lihat dari kegiatan unit pengolahan tersebut dapat menghasilkan limbah padat berupa kulit kerang yang cukup tinggi. Limbah yang dihasilkan dari unit pengolahan kerang tersebut menjadi masalah lingkungan dan kesehatan bagi masyarakat sekitar. Kondisi tersebut memotivasi masyarakat untuk mengolah limbah agar tidak terjadi pencemaran. Berdasarkan hal tersebut, untuk mengurangi dampak lingkungan dan kesehatan yang disebabkan oleh serbuk kulit kerang, berbagai penelitian telah Corresponding author. Telp.:

E-mail addresses: rofikatulkarimah@gmail.com dilakukan dan terus dikembangkan. Seperti halnya yang pernah dilakukan oleh Sahari dan Mijan (2011), dalam penelitiannya menggunakan cangkang kerang dalam bentuk kepingan dan serbuk yang menunjukan bahwa partikel cangkang kerang yang digunakan dalam campuran beton mengalami peningkatan kekuatan mekanik. Partikel kerang yang halus menyumbangkan kontribusi lebih kepada densitas, kekuatan, massa dan penyerapan air dibandingakan dengan kulit kerang dalam bentuk potongan dan kepingan.

Menurut Wen-Ten Kuo, dkk (2013) dalam penelitiannya yang mengevaluasi aplikasi praktis dari bahan limbah kerang tiram (Waste Oyster Shells/WOS) sebagai Controlled Low- Strength Materials (CLSM), dengan menggunakan variasi campuran $5 \%, 10 \%, 15 \%$, dan $20 \%$ WOS sebagai pengganti agregat halus. Hasil percobaan menunjukkan bahwa tidak ada penurunan yang signifikan dalam kuat tekan hingga 20\% dari subtansi pasir WOS sebagai pengganti agregat halus. Akan tetapi dalam pengunaanya kulit kerang sebagai agregat halus dapat mengisi pori - pori material yang dapat mengurangi tingkat penyerapan (absorbsi).. Kulit kerang sebagai pengganti agregat halus layak untuk pembuatan kontruksi bahan bangunan.

Menurut Arbi (2015), dalam penelitiannya menggunakan limbah kulit kerang sebagai agregat 
halus dengan variasi persentase terhadap berat agregat halus (pasir) yaitu $0 \%, 5 \%, 10 \%$, dan $15 \%$. Dari hasil pengujian kenaikan kuat tekan terjadi pada campuran 5\% dan 10\% limbah kulit kerang. Dari sini dapat diketahuai bahwa dengan menggunaka cangkang kerang berdampak positif terhadap nilai kuat tekan beton.

Menurut Hidayat (2015) dalam penelitiannya ini dimulai dari perencanaan campuran beton dengan mutu 22,5 MPa. Dibuat sampel beton campuran cangkang kerang dengan variasi persentase terhadap berat agregat halus (pasir) yaitu $0 \%, 10 \%, 25 \%$, $35 \%$, dan $50 \%$. Dari hasil pengujian kenaikan kuat tekan secara maksimum terjadi pada campuran $35 \%$. Dari sini dapat diketahuai perbandingan kuat tekan rata-rata beton campuran pada umur 28 hari meningkat dari kuat tekan rata-rata beton tanpa Cangkang Kerang.

Dari beberapa hasil penelitian menunjukkan bahwa kulit kerang sebagai pengganti agregat halus mampu menghasilkan densitas yang melebihi densitas beton normal. Melihat hal tersebut maka dilakukan pemanfaatan limbah serbuk kulit kerang sebagai bahan pengganti agregat halus ditinjau dari kuat tekan dan absorbsinya.

Serbuk kulit kerang berasal dari kulit kerang yang dibentuk oleh sel-sel cangkang (epitel mantel) yang mengeluarkan sekreta. Serbuk kulit kerang merupakan serbuk yang dihasilkan dari kulit kerang yang dihaluskan. Serbuk ini dapat digunakan sebagai bahan campuran atau tambahan pada pembuatan beton. Serbuk kulit kerang mengandung bahan kimia seperti yang di sajikan dalam tabel 1:

Tabel 1. Senyawa Kimia Kulit Kerang

\begin{tabular}{cc}
\hline Senyawa & Kadar $(\%)$ \\
\hline $\mathrm{CaCO}_{3}$ & 77.5 \\
$\mathrm{SiO}_{2}$ & 0,60 \\
$\mathrm{Fe}_{2} \mathrm{O}_{3}$ & $0 ., 14$ \\
$\mathrm{MgO}$ & 0.56 \\
$\mathrm{Al}_{2} \mathrm{O}_{3}$ & 0.71
\end{tabular}

Sumber : Balai Riset dan Standarisasi Industri Surabaya

Serbuk kulit kerang mengandung senyawa kimia pozzolan, yaitu mengandung zat kapur, alumina dan senyawa kimia silika sehingga berpotensi digunakan sebagai bahan baku beton alternatif yang diharapkan mampu mengurangi dampak negative terhadap kesehatan manusia dan lingkungan dan mampu memberikan kontribusi dalam dunia kontruksi.

2. Metode

2.1 Lokasi Penelitian
Pelaksanaan penelitian yang meliputi pemeriksaan serta pengujian bahan, pembuatan benda uji, perawatan dan pengujian beton dilakukan di Laboratorium Teknologi Beton, Fakultas Teknik, Jurusan Sipil Universitas Muhammadiyah Malang. Jln. Raya Tlogomas Malang.

\subsection{Rancangan Penelitian}

Penelitian ini dilakukan tiga tahap. Tahap pertama adalah tahap persiapan diawali dengan pengadaan semen, pasir, air dan serbuk kulit kerang. Kemudian dilanjutkan dengan pengujian material meliputi pasir, kerikil dan serbuk kulit kerang. Pengujian serbuk kulit kerang diperlakukan sama seperti pengujian agregat halus meliputi: Pengujian susunan gradasi, pengujian berat jenis dan pengujian penyerapan (absorbsi). Tahap kedua adalah tahap pembuatan benda uji berupa silinder beton, jumlah benda uji yang digunakan sebanyak 42 buah dengan ukuran 7,5x15 $\mathrm{cm}$. Tahap ketiga adalah tahap pengujian kuat tekan beton dan absorbsi beton. Properti benda uji tercantum dalam tabel 2 dan rancangan campuran beton tercantum pada tabel 3 sebagai berikut :

Tabel 2. Rancangan Benda Uji

\begin{tabular}{cccc}
\hline & & \multicolumn{2}{c}{ Jumlah Benda Uji } \\
\cline { 3 - 4 } $\begin{array}{c}\text { Persentase } \\
\text { Keranbah Kulit }\end{array}$ & $\begin{array}{c}\text { Benda } \\
\text { Uji }\end{array}$ & $\begin{array}{c}\text { Kuat } \\
\text { Tekan }\end{array}$ & Absorbsi \\
\hline $0 \%$ & Silinder & 3 & 3 \\
$5 \%$ & $7,5 \mathrm{x}$ & 3 & 3 \\
$10 \%$ & $15 \mathrm{~cm}$ & 3 & 3 \\
$15 \%$ & & 3 & 3 \\
$20 \%$ & & 3 & 3 \\
$25 \%$ & & 3 & 3 \\
$30 \%$ & & 3 & 3 \\
\hline Jumlah Benda Uji & 21 & 21 \\
\hline \multicolumn{2}{c}{ Total } & & 42 \\
\hline
\end{tabular}

Tabel 3. Rancangan Campuran Beton

\begin{tabular}{cccccc}
\hline & \multicolumn{5}{c}{ Komposisi Campuran } \\
\cline { 2 - 6 } $\begin{array}{c}\text { Variasi } \\
\text { Pengganti }\end{array}$ & $\begin{array}{c}\text { Semen } \\
(\mathbf{k g})\end{array}$ & $\begin{array}{c}\text { Pasir } \\
(\mathbf{k g})\end{array}$ & $\begin{array}{c}\text { LKKH } \\
(\mathbf{k g})\end{array}$ & $\begin{array}{c}\text { Batu } \\
\text { Pecah } \\
(\mathbf{k g})\end{array}$ & $\begin{array}{c}\text { Air } \\
(\mathbf{l})\end{array}$ \\
\hline $0 \%$ & 1,72 & 3.92 & 0 & 4,25 & 1,03 \\
$5 \%$ & 1,72 & 3.724 & 0.196 & 4,25 & 1,03 \\
$10 \%$ & 1,72 & 3.528 & 0.392 & 4,25 & 1,03 \\
$15 \%$ & 1,72 & 3.332 & 0.588 & 4,25 & 1,03 \\
$20 \%$ & 1,72 & 3.136 & 0.784 & 4,25 & 1,03 \\
$25 \%$ & 1,72 & 2.94 & 0.98 & 4,25 & 1,03 \\
\hline
\end{tabular}




\begin{tabular}{llllll}
\hline $30 \%$ & 1,72 & 2.744 & 1.176 & 4,25 & 1,03 \\
\hline
\end{tabular}

\section{Diagram Alir Penelitian}

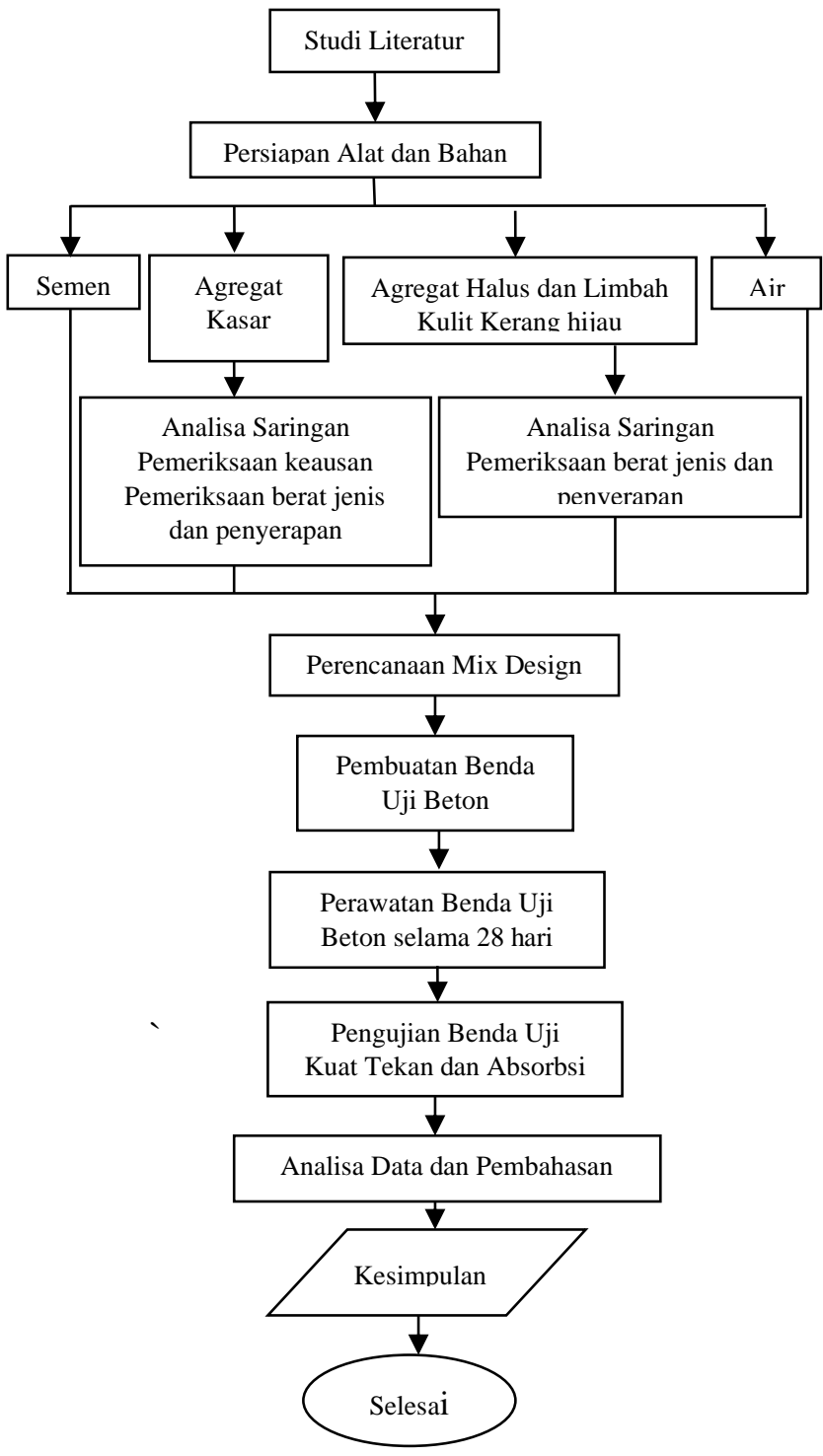

Gambar 1. Digram Alir Penelitian

\section{Hasil dan Pembahasan}

\subsection{Hasil Pengujian Material Beton}

\subsubsection{Agregat Halus}

Hasil pemeriksaan agregat halus berupa pasir dan limbah kulit kerang hijau dapat dilihat pada tabel 4 sebagai berikut:

Tabel 4. Hasil Pemeriksaan Agregat Halus

\begin{tabular}{cccc}
\hline $\begin{array}{c}\text { Jenis } \\
\text { Pemeriksaan }\end{array}$ & Standart & Syarat & $\begin{array}{c}\text { Hasil } \\
\text { Pengujian }\end{array}$ \\
\hline Analisa & ASTM & Fm $=2-$ & Fm $=3.1$ \\
Saringan & C-136- & 3.5 & \\
Pasir & 46 & & $\mathrm{Fm}=2.8$ \\
Analisa & & & \\
$\begin{array}{c}\text { Saringan } \\
\text { Limbah Kulit }\end{array}$ & & & \\
Kerang & & & \\
$\begin{array}{c}\text { Berat jenis } \\
\text { pasir }\end{array}$ & ASTM & $\begin{array}{c}2.5-2.7 \\
\mathrm{gr} / \mathrm{cm}^{3}\end{array}$ & $2.7 \mathrm{gr} / \mathrm{cm}^{3}$ \\
\hline
\end{tabular}

\begin{tabular}{cccc}
\hline $\begin{array}{c}\text { Berat jenis } \\
\text { limbah kulit } \\
\text { kerang }\end{array}$ & 68 & & $2.51 \mathrm{gr} / \mathrm{cm}^{3}$ \\
$\begin{array}{c}\text { Penyerapan } \\
\text { pasir }\end{array}$ & ASTM & $<3 \%$ & $1.42 \%$ \\
$\begin{array}{c}\text { Penyerapan } \\
\text { limbah kulit }\end{array}$ & 68 & & $1.83 \%$ \\
kerang & & & \\
\hline
\end{tabular}

\subsubsection{Agregat Kasar}

Hasil pemeriksaan agregat kasar dapat dilihat pada tabel 5 sebagai berikut :

\begin{tabular}{|c|c|c|c|}
\hline $\begin{array}{c}\text { Jenis } \\
\text { Pemeriksaan } \\
\end{array}$ & Standar & Syarat & $\begin{array}{c}\text { Hasil } \\
\text { Pengujian }\end{array}$ \\
\hline $\begin{array}{c}\text { Analisa } \\
\text { saringan }\end{array}$ & $\begin{array}{l}\text { ASTM } \\
\text { C-136- } \\
46\end{array}$ & $5-7$ & $\begin{array}{c}\text { Besar butiran } \\
\max 20 \mathrm{~mm}, \\
F M=5.04\end{array}$ \\
\hline Berat Jenis & $\begin{array}{c}\text { ASTM } \\
\text { C-128- } \\
68\end{array}$ & $\begin{array}{c}2.5-2.7 \\
\mathrm{gr} / \mathrm{cm}^{3}\end{array}$ & $2.64 \mathrm{gr} / \mathrm{cm}^{3}$ \\
\hline Absorbsi & $\begin{array}{c}\text { ASTM } \\
\text { C-128- } \\
68\end{array}$ & $<3 \%$ & $1.46 \%$ \\
\hline (Keausan) & $\begin{array}{l}\text { ASTM } \\
\text { C-131 }\end{array}$ & $<40 \%$ & $13,72 \%$ \\
\hline
\end{tabular}

\subsection{Hasil Pengujian Benda Uji \\ 3.2.1 Kuat Tekan Beton}

Pengujian kuat tekan beton dapat dilihat pada tabel 7 berikut :

Tabel 7. Hasil Pemeriksaan Kuat Tekan Beton

\begin{tabular}{ccc}
\hline No & Campuran & $\begin{array}{c}\text { kuat tekan } \\
\text { (Mpa) }\end{array}$ \\
\hline $\mathbf{1}$ & $0 \%$ & 24,13 \\
$\mathbf{2}$ & $5 \%$ & 24,81 \\
$\mathbf{3}$ & $10 \%$ & 25,58 \\
$\mathbf{4}$ & $15 \%$ & 24.49 \\
$\mathbf{5}$ & $20 \%$ & 23.6 \\
$\mathbf{6}$ & $25 \%$ & 23.36 \\
$\mathbf{7}$ & $30 \%$ & 22.55 \\
\hline
\end{tabular}

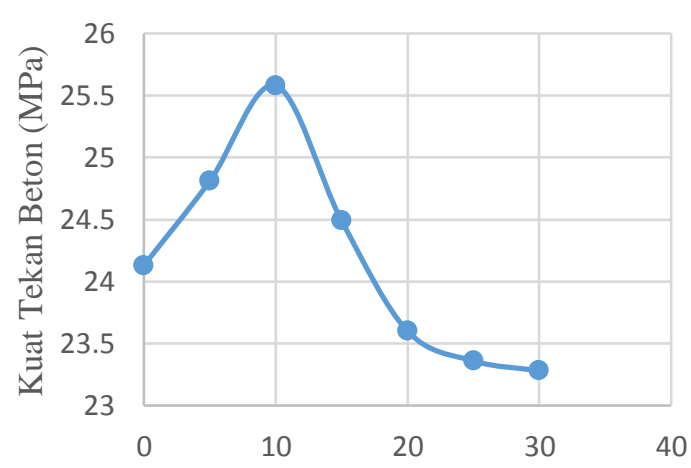

Variasi Prosentase Serbuk Kulit Kerang $(\%)$

Gambar 2. Hubungan antara Kuat Tekan dengan Prosentase Campuran 
Dari data hasil pengujian diatas dapat dilihat bahwa serbuk kulit kerang sebagai bahan pengganti sebagian pasir mengalami kenaikan seiring dengan bertambahnya variasi prosentase serbuk kulit kerang. Kuat tekan maksimum sebesar 25,58 $\mathrm{MPa}$ pada variasi prosentase serbuk kulit kerang $10 \%$. Setelah itu kuat tekan menurun seiring dengan bertambahnya prosentase variasi serbuk kulit kerang. Hasil kuat tekan beton dengan menggunakan serbuk kulit kerang sebagai pengganti sebagian pasir pada campuran beton dapat menaikkan nilai kuat tekan, hal ini sama dengan penelitian sebelumnya yang dilakukan oleh (Arbi, 2015) dan penelitian (Hidayat, 2015).

\subsubsection{Absorbsi}

Hasil pengujian penyerapan air (absorbsi) pada beton dapat dilihat pada tabel 8 berikut ini :

\begin{tabular}{ccc}
\multicolumn{3}{c}{ Tabel 8. Nilai Absorbsi Beton } \\
\hline No & $\begin{array}{c}\text { Variasi } \\
\text { Campuran }\end{array}$ & $\begin{array}{c}\text { Nilai } \\
\text { Absorbsi }\end{array}$ \\
\hline $\mathbf{1}$ & $0 \%$ & 1.41 \\
$\mathbf{2}$ & $5 \%$ & 1.74 \\
$\mathbf{3}$ & $10 \%$ & 2.1 \\
$\mathbf{4}$ & $15 \%$ & 2.3 \\
$\mathbf{5}$ & $20 \%$ & 2.46 \\
$\mathbf{6}$ & $25 \%$ & 2.75 \\
$\mathbf{7}$ & $30 \%$ & 3.08 \\
\hline
\end{tabular}

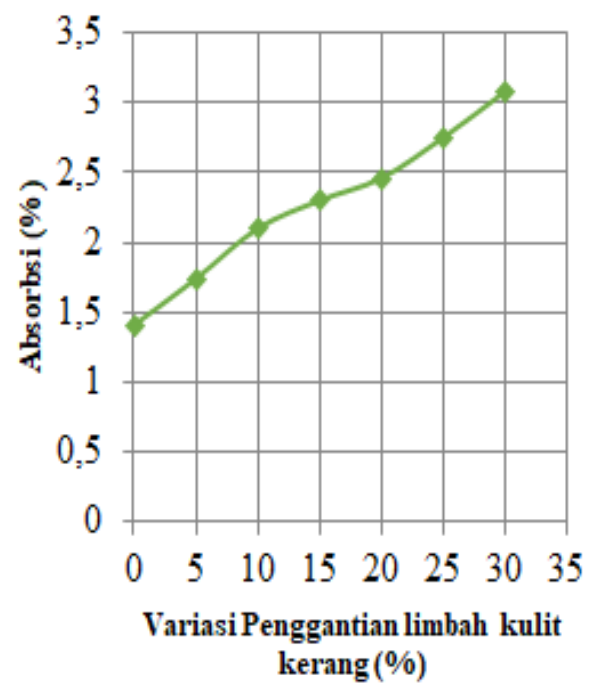

Gambar 3. Hubungan antara nilai absorbsi dengan variasi campuran

Dari hasil absorbsi pada tabel diatas didapat bahwa semakin banyaknya variasi serbuk kulit kerang yang ditambahkan maka nilai absorbs mengalami kenaikan. Beton dengan variasi serbuk kulit kerang $0 \%$ mempunyai nilai absorbsi yang paling kecil yaitu sebesar $1,41 \%$ sedangkan variasi serbuk kulit kerang 30\% nilai absorbsinya sebesar $3,08 \%$. Kondisi ini bisa disebabkan karena proses pengikatan yang kurang baik sehingga terbentuk rongga - rongga udara yang mudah dimasuki oleh air. Selain itu penyerapan yang terjadi pada penambahan serbuk kulit kerang sebagai agregat halus cukup besar. Akan tetapi berdasarkan SNI S36-1990-03 nilai penyerapan pada beton maksimum $2,5 \%$ berat kering oven untuk perendaman $10 \pm 5$ menit, dan 6,5\% berat kering oven untuk perendaman selama 24 jam. Berdasarkan batasan batasan yang telah disebutkan diatas maka penambahan serbuk kulit kerang sebagai agregat halus sebesar $5 \%$ sampai $30 \%$ pada penelitian ini masih tergolong dalam beton kedap terhadap air.

\section{Kesimpulan}

Berdasarkan hasil penelitian dan

1. Penggunaan serbuk kulit kerang hijau sebagai pengganti sebagian agregat halus pada beton dapat menaikkan kuat tekan beton pada variasi prosentase serbuk kulit kerang 5\% - 10\%.

2. Penggunaan serbuk kulit kerang hijau sebagai pengganti sebagian agregat halus pada beton dapat menaikkan nilai absorbsi seiring dengan bertambahnya prosentase serbuk kulit kerang.

\section{Saran}

Beberapa saran yang dapat diusulkan pada penelitian ini antara lain :

Perlu dilakukan penelitian lanjutan pada serbuk kulit kerang dimana serbuk kulit kerang berfungsi pada filler campuran beton.

\section{DAFTAR PUSTAKA}

Badruz Zaman, 2015, Strategi Petani Tambak Dalam Meningkatkan Kesejahteraan Ekonomi Melalui Usaha Tambak Kerang Hijau Di Desa Campurejo Kecamatan Panceng Kabupaten Gresik, Universitas Islam Negeri Sunan Ampel Surabaya.

Farida Sahari, Mijan Anisa N, 2011, Cockle Shell As Alternative Contruction Material For Artificial Reef, Universitas Malaysia Serawak.

Hasbi M Arbi, 2015, Pengaruh Subtitusi Cangkang Kerang Dengan Agregat Halus Terhadap Kuat Tekan Beton, Jurusan Teknik Sipil, Fakultas Teknik, Universitas Al- Muslim.

Hidayat Pebri P, 2015, Penggunaan Cangkang Kerang Darah Sebagai Agregat Halus Pada Campuran Beton, Jurusan Teknik Sipil dan Lingkungan, Universitas Lambung Mangkurat.

Wen-Ten Kuo, Her-Yeung Wang dkk, 2013, Engineering Properties Of Controlled Low - Strength Materials Containing Waste 
Oyster Shells, Departement of Civil Engineering and Disaster Mitigation

Technology, National Kaohsiung

University 
